\title{
Evolution of volatile compounds from milk to curd during manufacturing of Mozzarella
}

\author{
Giuseppe Natrella ${ }^{*}$, Giuseppe Gambacorta ${ }^{1}$, \\ Pasquale De Palo², Jose Manuel Lorenzo ${ }^{3}$, Michele Faccia'
}

\begin{abstract}
'University of Bari, Department of Soil, Plant and Food Sciences, Via Amendola 165/A, 70126, Bari, Italy 2University of Bari, Department of Veterinary Medicine, S.P. Casamassima km 3, 70010, Valenzano, Bari, Italy ${ }^{3}$ Centro Tecnológico de la Carne de Galicia, Parque Tecnológico de Galicia, Rúa Galicia № 4, San Cibrán das Viñas, 32900 Ourense, Spain

*Corresponding author: Giuseppe.natrella@uniba.it
\end{abstract}

\section{Abstract}

The aim of this study was to investigate the evolution of the volatile compounds (VOC) from milk to curd during mozzarella manufacturing, in connection with the technique used for curd acidification (traditional = natural whey starter fermentation; industrial = direct acidification by citric acid addition). Overall, 40 compounds were identified from the entire set of samples, belonging to different chemical classes. All compounds detected in milk were also found in the curd, but at much higher concentration. In addition, many other compounds formed during curd production. By comparison of the samples from the 2 acidification techniques, and analysing the scientific literature to explain the source of the volatile compounds, it was found that microbial activity played a main role in VOC formation. In fact, the curd obtained by natural whey starter fermentation showed the most complex profile, whereas that of the curd obtained by direct acidification was much simpler. The most important odour-active compounds that could contribute to flavour of the curd made by traditional technology were 3-methylbutanal, ethyl acetate and 2,3-butanedione, responsible for ethereal, fruity and buttery odour. For direct acidification they were 3-methylbutanal (at lower level), nonanal and decanal (herbal/fruity odour). The PCA analysis showed clear clusterization of the three types of samples: milks and direct acidified curds were rather close in the bi-plot graph, whereas traditional curds were spread all along the space. The research is currently in progress, for assessing the evolution of the volatile compounds during the next technological steps of mozzarella manufacturing.

\section{Key words: volatile organic compounds, milk, curd, mozzarella, acidification}

\section{Introduction}

Table mozzarella (high moisture type, 60-65 \% water content) is the most popular among the "pasta filata” cheeses, a group of dairy products character- ised by rearrangement of the curd by plasticization and stretching process using hot water (McMahon and Oberg, 2017). It is traditionally manufactured from cow's or buffalo milk, even though the procedure for making it from sheep and goat milk has 
been recently reported (Faccia et al., 2015). For plasticization the curd needs to be suitably acidified, in order to cause partial casein demineralization. For cow's mozzarella, acidification can be performed by two different ways: direct addition of organic acids to milk or fermentation of the curd by lactic acid bacteria (Guidone et al., 2016). Fermentation by natural autochthonous whey culture represents the original method, but currently it is only used in traditional dairies due high costs and difficulty in standardization. Differently, direct acidification by adding citric or lactic acid is mostly used in industrial dairies. Despite of the worldwide manufacturing of mozzarella, scientific information on aroma of this cheese are very scarce (Moio et al., 1993; Pisano et al., 2016). The acidification step should be an important phase for the development of aroma in mozzarella, since the product does not undergo the ripening process and is kept under refrigeration until consumption (Faccia et al., 2014; 2019). In general, only few studies have dealt with the formation of VOCs from milk to curd (Partidário et al., 1998). However, the VOCs profile of the curd is expected to depend on the type of cheese, since the processes for curd production strongly vary. The aim of the present study was to investigate the evolution of VOCs from milk to curd during the manufacturing process of table cow's mozzarella. In particular, acidification by direct addition of citric acid and by whey starter fermentation were compared by using the Solid Phase Microextraction technique (SPME) coupled to mass-spectrometry gas chromatography (GC-MS).

\section{Materials and methods}

\section{Milk and curd samples}

The samples were obtained by 3 cheese making trials performed at a traditional dairy located in the town of Gioia del Colle (Puglia, Italy). Each trial was composed of two vats containing $100 \mathrm{~L}$ raw milk taken from the same farm, which were processed by direct acidification and whey starter fermentation, respectively. For direct acidification curd (DAC), $10 \%$ citric acid solution was added to cold milk until pH reached about 5.7, then rennet was added for coagulation. For the whey starter curd
(WSC), $3 \%$ v/v autochthonous whey starter culture was added to milk at room temperature, and after about 10 minutes, rennet was added. In this case, milk coagulation took place at pH 6.1-6.2. Autochthonous starter derived from the whey obtained from cheese making of the previous day, heated to $44{ }^{\circ} \mathrm{C}$ and left to ferment at room temperature for about $24 \mathrm{~h}$. In both cases, after acid or starter addition the milk was coagulated at $36^{\circ} \mathrm{C}$ by addition of calf rennet at the doses normally used in the factory (18 and $25 \mathrm{~g} 100 \mathrm{~L}^{-1}$ of milk for DAC and WSC, respectively. The difference depended on the different $\mathrm{pH}$ value in milk). After coagulation, the curd was cut to the size of a hazelnut grain and left to rest. Then, in the direct acidification process the whey was removed after 10 min since the curd was already demineralised and ready to be stretched. Differently, for the whey starter process, the whey was drained after 3 hours in order to allow the curd maturation to reach the suitable" stretching $\mathrm{pH}^{\prime}$ (about 5.2-5.3). In both cases, after whey removal, samples of curd were taken, put into plastic bags under refrigerated conditions and transported to the laboratories for VOCs analyses.

\section{Chemical and VOCs analysis}

Milk and curds underwent to the following chemical analyses: for milk, $\mathrm{pH}(\mathrm{pH}$ meter with glass electrode, Hamilton, USA), fat, protein and lactose (infrared analysis by Milko Scan FT1, Foss, Denmark); for curd, $\mathrm{pH}$ ( $\mathrm{pH}$ meter with Polyplast penetration electrode, Hamilton, USA), moisture (IDF, 1986), fat (Soxhlet method), total protein (Kjeldhal method), lactose (HPLC with refractive index detection as indicated by Trani et al., 2017). The volatile compounds were extracted from milk and curd samples by solid phase micro-extraction (SPME). The samples were weighed $(1 \pm 0.05 \mathrm{~g})$ into $20 \mathrm{~mL}$ vials, closed by a rubber septum and an aluminium cap; for milk sample $0.2 \mathrm{~g} \mathrm{NaCl}$ was added to increase the ionic strength. Both samples were added with internal standard (81.3 ng 3-pentanone) to perform a semi-quantitation. Before extraction, stabilization of the headspace in the vial was obtained by equilibration for $10 \mathrm{~min}$ at $37^{\circ} \mathrm{C}$. The extraction was carried out using a divinylbenzene/carboxen/polydimethylsiloxane (DVB/CAR/ PDMS) 50/30 mm SPME fibre assembly (Supelco, 
Bellefonte, PA, USA) at $37^{\circ} \mathrm{C}$ for $15 \mathrm{~min}$. The fibre was desorbed at $220^{\circ} \mathrm{C}$ for $2 \mathrm{~min}$ in the injection port of the gas chromatograph, operating in splitless mode. The GC-MS analyses were performed using a Trace1300 gas chromatograph equipped with a mass spectrometer ISQ Series 3.2 SP1. The compounds were separated on a Thermo capillary column TR-WAX MS (20 m, $0.1 \mathrm{~mm}, 0.1 \mathrm{~mm})$, under the following conditions: injection port temperature, $220^{\circ} \mathrm{C}$; oven temperatures, $50^{\circ} \mathrm{C}$ for 0.1 min then $13^{\circ} \mathrm{C} \mathrm{min}{ }^{-1}$ to $180^{\circ} \mathrm{C}, 18^{\circ} \mathrm{C} \mathrm{min}^{-1}$ to $220^{\circ} \mathrm{C}$ final isothermal for 1.5 min for curd samples and 3 min for milk samples. Mass detector was set at the following conditions: detector voltage, $1700 \mathrm{~V}$; source temperature, $250^{\circ} \mathrm{C}$; ionization energy, $70 \mathrm{eV}$; scan range 33-200 amu. Peak identification was done by means of Xcalibur V2.0 software, in particular Qual Browse, by matching with the reference mass spectra of NIST library.

\section{Statistical analysis}

Statistical treatment of the data was carried out using XLSTAT software (Microsoft) for one-way analysis of variance (ANOVA), and OriginPro2017 (OriginLab Corporation) for PCA analysis.

TABLE 1. Chemical gross composition (\%) of the milk and curds from the experimentation (average of 3 cheese making trials)

\begin{tabular}{llll}
\cline { 2 - 4 } & Milk & DAC curd & WSC curd \\
\hline $\mathrm{pH}$ & $6.74( \pm 0.02)$ & $5.65( \pm 0.03)^{\mathrm{a}}$ & $5.23( \pm 0.05)^{\mathrm{b}}$ \\
\hline Dry matter & $86.97( \pm 0.16)$ & $55.4( \pm 2.2)$ & $53.78( \pm 1.4)$ \\
\hline Protein & $3.33( \pm 0.04)$ & $20.51( \pm 0.9)$ & $21.11( \pm 0.6)$ \\
\hline Fat & $3.72( \pm 0.11)$ & $22.52( \pm 1.8)$ & $23.33( \pm 0.9)$ \\
\hline Lactose & $4.86( \pm 0.02)$ & $1.52( \pm 0.2)^{\mathrm{a}}$ & $0.51( \pm 0.11)^{\mathrm{b}}$ \\
\hline
\end{tabular}

Values bearing different superscripts are different at $\mathrm{P}<0.05$

\section{Results and discussion}

The average chemical gross composition of milk and curds from the experimentation is shown in Table 1. The milk used in the three cheese making trials had only slight variations, whereas significant differences were observed in $\mathrm{pH}$ and lactose concentration in the curds. They were expected, since these two chemical parameters are closely related to the method of acidification. The difference in $\mathrm{pH}$ depends on the kinetic of casein demineralization: DAC method is more effective in sequestering calcium from the casein micelle than WSC, and curd stretching takes place at higher $\mathrm{pH}$ (Mucchetti and Neviani, 2006). However, such differences are not so high to expect deep variations in VOC formation (5.65 versus 5.23, respectively). The difference in lactose are connected to different microbial activity: DAC does not involve lactic fermentation, and lactose is poorly degraded; differently, the WSC method is based on lactic fermentation, and part of the sugar is metabolized by the starter microflora. Table 2 shows the volatile compounds identified in the entire set of samples. Overall, 40 compounds were found: 7 aldehydes, 10 methyl ketones, 8 alcohols, 2 sulphur compounds, 8 acids, 2 esters, 1 terpene, 2 aliphatic hydrocarbons. Figure 1 resumes the evolution of the volatile compounds during processing. None of the milk compounds disappeared, however, they represented a very low percentage of total VOCs in the curds. As expected, the volatile profile of milk was poorer than that of the curd, both under the qualitative and quantitative point of view. Several compounds were found both in milk and curd, others were newly formed. Among the former, acetic acid had huge increase during processing: it was 42 and 13 times higher in WSC and DAC, respectively than in milk. According to the literature, in fresh dairy products it mainly derives from bacterial metabolism of citrate and sugars, whereas in ripened cheese it is also formed by oxidative deamination of glycine, alanine and serine (Partidário at al., 1998). Another important compound was nonanal; its concentration was about 9 times higher in WSC and 5 times higher in DAC than milk. It should derive from $\beta$-oxidation of unsaturated fatty acids (McSweeney and Sousa, 2000). Concentration of hexanoic and butanoic acids almost triplicated in WSC samples, whereas a less significant increase was found in DAC. Since these compounds mainly derive from enzymatic degradation of milk triglycerides, the differences between the 2 types of sample should be ascribed to some lipolytic activity by the starter microflora. Other compounds had slight increase, but with low or no statistical significance, such as heptanal, 6-methyl-5-hepten-2-one, dimethyl sulfone and nonanoic acid. Among the newly formed 
TABLE 2. Total volatile organic compounds detected in milk (M), citric acid curd (DAC) and whey starter curd (WSC), expressed as ppb

\begin{tabular}{|l|l|l|}
\hline$M$ & DAC & WSC
\end{tabular}

\section{Aldehydes}

\begin{tabular}{|c|c|c|c|}
\hline 3-methyl butanal & - & $71.07^{\mathrm{B}}$ & $215.66^{A}$ \\
\hline hexanal & $1.04^{\mathrm{A}}$ & $2.58^{\mathrm{A}}$ & $12.08^{\mathrm{A}}$ \\
\hline heptanal & $0.20^{\mathrm{A}}$ & $1.05^{\mathrm{A}}$ & $2.48^{\mathrm{A}}$ \\
\hline octanal & $0.49^{B}$ & $1.43^{\mathrm{AB}}$ & $4.08^{\mathrm{A}}$ \\
\hline nonanal & $3.52^{\mathrm{B}}$ & $14.84^{\mathrm{AB}}$ & $27.98^{\mathrm{A}}$ \\
\hline decanal & $2.01^{\mathrm{A}}$ & $2.03^{A}$ & $2.62^{\mathrm{A}}$ \\
\hline benzaldehyde & - & - & 17.08 \\
\hline \multicolumn{4}{|l|}{ Ketones } \\
\hline acetone & $67.18^{\mathrm{A}}$ & $52.25^{\mathrm{A}}$ & $82.27^{A}$ \\
\hline 2-butanone & $4.50^{\mathrm{A}}$ & $4.35^{\mathrm{A}}$ & $13.92^{\mathrm{A}}$ \\
\hline Diacetyl (2,3-butanedione) & - & $30.35^{\mathrm{B}}$ & $159.42^{\mathrm{A}}$ \\
\hline 2,3 pentanedione & - & $0.69^{\mathrm{B}}$ & $28.48^{\mathrm{A}}$ \\
\hline 2-heptanone & - & $4.62^{\mathrm{B}}$ & $18.46^{\mathrm{A}}$ \\
\hline acetoin & - & $207.24^{\mathrm{B}}$ & $865.79^{A}$ \\
\hline 6-methyl-5-hepten-2-one & $0.88^{\mathrm{A}}$ & $1.72^{\mathrm{A}}$ & $2.01^{\mathrm{A}}$ \\
\hline 2-hydroxy-3-pentanone & - & - & 5.71 \\
\hline 2-nonanone & - & $1.06^{\mathrm{B}}$ & $4.37^{A}$ \\
\hline 2-undecanone & - & - & 0.85 \\
\hline \multicolumn{4}{|l|}{ Alcohols } \\
\hline ethanol & - & $6.48^{\mathrm{B}}$ & $461.09^{A}$ \\
\hline 3-methyl,1-butanol & - & $26.88^{\mathrm{B}}$ & $538.68^{A}$ \\
\hline 3-methyl-2-buten-1-ol & - & - & 1.26 \\
\hline 2-methoxy-1-methylethoxy,2-propanol & $0.28^{A}$ & $1.45^{\mathrm{A}}$ & $0.76^{A}$ \\
\hline 2-propyl-1-pentanol & $1.48^{\mathrm{A}}$ & - & $0.30^{A}$ \\
\hline 2-methoxypropoxy, 2-propanol & - & $2.35^{\mathrm{A}}$ & $0.68^{A}$ \\
\hline 2-octyloxy-ethanol & - & $20.58^{A}$ & $6.31^{\mathrm{A}}$ \\
\hline phenylethyl alcohol & - & $1.04^{\mathrm{B}}$ & $4.37^{\mathrm{A}}$ \\
\hline \multicolumn{4}{|l|}{ Sulfur compounds } \\
\hline dimethyl sulfide & $0.12^{\mathrm{B}}$ & $2.64^{\mathrm{A}}$ & - \\
\hline dimethyl sulfone & $1.97^{\mathrm{A}}$ & $1.29^{\mathrm{A}}$ & $2.06^{A}$ \\
\hline \multicolumn{4}{|l|}{ Acids } \\
\hline acetic acid & $2.69^{B}$ & $35.66^{\mathrm{B}}$ & $109.91^{\mathrm{A}}$ \\
\hline butanoic acid & $5.09^{B}$ & $6.82^{\mathrm{B}}$ & $15.57^{\mathrm{A}}$ \\
\hline 3-methyl-butanoic acid & - & $0.47^{A}$ & $0.69^{A}$ \\
\hline hexanoic acid & $7.87^{\mathrm{B}}$ & $9.41^{\mathrm{B}}$ & $20.79^{A}$ \\
\hline heptanoic acid & - & $0.60^{A}$ & $1.11^{\mathrm{A}}$ \\
\hline octanoic acid & $4.96^{\mathrm{AB}}$ & $3.75^{\mathrm{B}}$ & $8.25^{\mathrm{A}}$ \\
\hline nonanoic acid & $1.37^{\mathrm{A}}$ & $2.12^{\mathrm{A}}$ & $2.08^{\mathrm{A}}$ \\
\hline decanoic acid & $3.37^{\mathrm{A}}$ & $0.95^{\mathrm{B}}$ & $2.65^{\mathrm{AB}}$ \\
\hline \multicolumn{4}{|l|}{ Esters } \\
\hline ethyl acetate & - & $3.71^{\mathrm{B}}$ & $685.36^{A}$ \\
\hline 1-butanol-3-methyl-acetate & - & - & 1.945 \\
\hline \multicolumn{4}{|l|}{ Miscellaneous } \\
\hline styrene & - & 0.71 & - \\
\hline hexane & $1.27^{\mathrm{A}}$ & $2.06^{\mathrm{A}}$ & $4.24^{\mathrm{A}}$ \\
\hline heptane & $0.76^{\mathrm{B}}$ & $3.54^{\mathrm{AB}}$ & $26.31^{A}$ \\
\hline
\end{tabular}


compounds during processing, 3-methylbutanal was much more abundant in WSC $(3$ times higher) than DAC. In foods, it is generated by non-enzymatic browning reaction of leucine induced by heating (Contarini et al., 1997), but in our study the heating level during processing was too low for allowing significant Maillard reaction. As a consequence, it should derive by bacteria and yeast activity on leucine or isoleucine (Valero et al., 2001; Afzal et al., 2017). 2-heptanone and 2-nonanone were 4 times higher in WSC: they should come from $\beta$-oxidation of saturated fatty acids followed by a
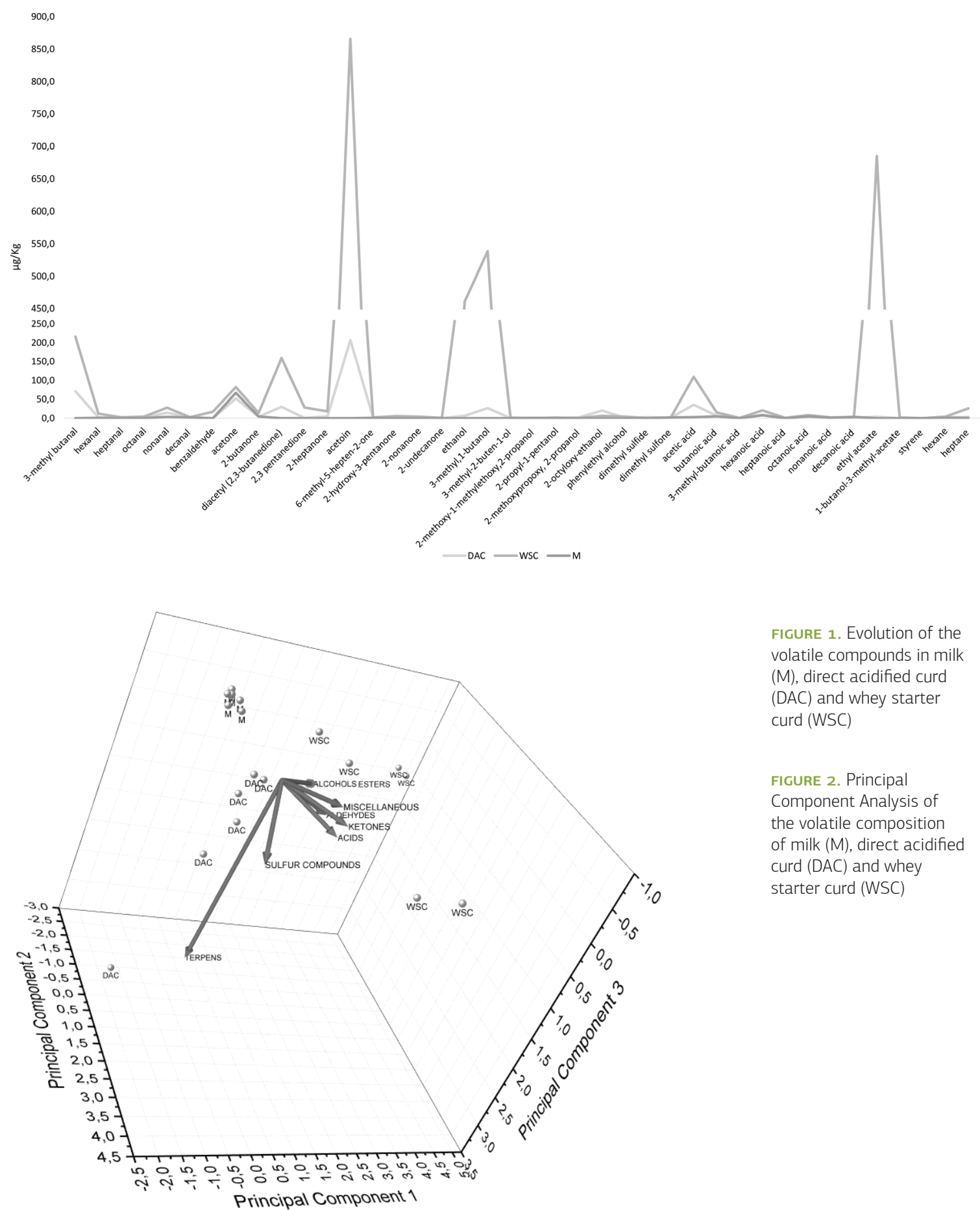

FIGURE 1. Evolution of the volatile compounds in milk (M), direct acidified curd (DAC) and whey starter curd (WSC)

FIGURE 2. Principal Component Analysis of the volatile composition of milk (M), direct acidified curd (DAC) and whey starter curd (WSC) 
first decarboxylation and successive $\beta$-ketoacids decarboxylation (Dursun et al., 2017). Diacetyl, acetoin and ethanol are known to be primary compounds of volatilome of lactic acid bacteria and yeasts fermentation, respectively (Bassette et al., 1966; Zeppa et al., 2008; Bertuzzi et al., 2018). As expected, their concentration was much higher in WSC than DAC: diacetyl and acetoin were 4-5 times higher, whereas ethanol was about 76 times higher. This latter result suggests an important role of yeasts: in fact, these microorganisms are common compounds of microbiota of the natural whey starters for mozzarella (Binetti et al., 2013; Trani et al., 2016). A second alcohol, 3-methylbutanol, should be a conversion product of 3-methylbutanal: it was detected at very high level in WSC (20 times higher than DAC). Ethyl acetate was another characterizing compound of WSC samples: on the average, it was 28 times higher than in DAC: it could have been generated by heat-catalysed esterification reactions between ethanol and acetic acid (Vazquez Landaverde et al., 2005). Some compounds were only detected in WSC: benzaldehyde, 2-hydroxy-3-pentanone, 2-undecanone, 3-methyl2-buten-1-ol, 1-butanol-3-methyl-acetate. They are mostly generated during curd maturation due to bacterial fermentations, proteolysis or lipolysis (Bassette et al., 1966; Yvon et al., 2001; Bertuzzi et al., 2018).

TABLE 3. "Aromatic backbone" of milk (M), direct acidified curd (DAC) and whey starter curd (WSC) and VOCs odour description

\begin{tabular}{|c|c|c|c|c|c|}
\hline & \multicolumn{3}{|c|}{ Aroma value } & \multirow[t]{2}{*}{ OT } & \multirow[t]{2}{*}{ Odour description } \\
\hline & M & CCA & CWS & & \\
\hline \multicolumn{6}{|l|}{ Aldehydes } \\
\hline 3-methyl butanal* & 0 & 355 & 1078 & $0,2[1]$ & Powerful penetrating, acrid odour, apple-like odour \\
\hline hexanal & 0 & 1 & 3 & $4,5[2]$ & Green, fatty, fruity \\
\hline octanal* & 0 & 1 & 3 & $1,4[3]$ & Aldehydic, waxy, citrus orange with a green peely nuance \\
\hline nonanal* & 4 & 15 & 28 & $1[3]$ & Sweet, orange, orange peel \\
\hline decanal & 20 & 20 & 26 & $0,1[2]$ & Sweet, aldehydic, orange, waxy and citrus rind \\
\hline \multicolumn{6}{|l|}{ Ketones } \\
\hline 2,3-butanedione* & 0 & 13 & 69 & $2,3[4]$ & strong buttery \\
\hline 2,3-pentanedione* & 0 & 0 & 1 & $30[5]$ & $\begin{array}{l}\text { buttery diacytl-like, fermented dairy and creamy, } \\
\text { popcorn buttery }\end{array}$ \\
\hline acetoin* & 0 & 0 & 1 & $800[1]$ & Intense buttery, creamy \\
\hline 2-nonanone* & 0 & 0 & 1 & $5[2]$ & $\begin{array}{l}\text { Fruity, sweet, waxy, soapy, cheese, green herbaceous, } \\
\text { coconut like }\end{array}$ \\
\hline \multicolumn{6}{|l|}{ Alcohols } \\
\hline ethanol & 0 & 1 & 58 & $8[3]$ & Pleasant, weak, ethereal, vinous odour \\
\hline 3-methyl,1-butanol* & 0 & 0 & 8 & $71[6]$ & Banana, alcohol, fruity \\
\hline phenylethyl alcohol* & 0 & 1 & 4 & $1,2[3]$ & Characteristic rose-like odour \\
\hline \multicolumn{6}{|l|}{ Sulfur compounds } \\
\hline dimethyl sulfide* & 0 & 9 & 0 & $0,3[1]$ & Unpleasant odour of wild radish, cabbage-like \\
\hline \multicolumn{6}{|l|}{ Esters } \\
\hline ethyl acetate* & 0 & 1 & 137 & $5[3]$ & Ethereal, fruity, green \\
\hline
\end{tabular}

* = significantly different at $\mathrm{p}<0.05$. OT= Odour threshold $(\mu \mathrm{g} / \mathrm{L})$ in water

[1] Buttery, 1990; [2] Buttery, 1988; [3] Burdock, 2005; [4] Fors, 1998; [5] Blank, 1992; [6] Czerny, 2008 
Table 3 shows the "aromatic backbone" of the two types of mozzarella. It is composed of the VOCs that exceeded the aroma threshold concentration (Aroma Value $>1$ ), calculated on the basis of bibliographic data. The milk samples had just 2 compounds that exceeded such value: decanal and nonanal, which presents herbal/fruity odour. These two compounds were also among the most important odour-active VOCs in DAC samples, in which 10 compounds exceeded $A V>1$. The most important of them was 3-methylbutanal ( $A V=355)$, which is responsible of acrid or apple-like odour, depending on the concentration. The WSC samples presented the most complex aromatic backbone, with 13 compounds potentially involved into aroma perception. The most important were 3-methylbutanal ( $A V=1078)$, ethyl acetate ( $A V=137)$ and 2,3-butanedione $(A V=69)$, responsible for ethereal, fruity and buttery odour. These results point out the huge importance of fermentations on the development of aroma in mozzarella and confirm that the "primary aroma” (i.e. odour-active compounds already present in milk) can play a role only in the case of direct acidification technology. This consideration is further supported by Figure 2, which reports the Principal Component Analysis of the data set. As it can be seen, the milk samples are all gathered together, and the DAC ones are near them (except for one that is characterized by characteristic terpenes content). Differently, the WSC samples are spread all along the space. Being the graph a bi-plot, it is possible to observe that the WSC scores (dots) and loadings (arrow, variable correlation) are mostly on the same direction, which means that such samples are richer in esters, methyl ketones, acids and alcohols than the other samples.

\section{Conclusions}

The main outcome of the present experimentation was the description of the differences in the VOC profile of the two types of curds. Considering that the two acidification techniques only differed in the presence/absence of starter added, the most part of the differences observed should be connected to different microbial activity. This conclusion is also supported by the fact that, according to the scientific literature, the most abundant compounds detected derives from microbial metabolism. Among the possible odour-active compounds, only 2 were also detected in milk, suggesting scarce contribution of milk VOC to curd aroma. It was concluded that the VOC profile in curd from making mozzarella is mainly driven by microbial metabolism rather than to a concentration effect consequent to coagulation and whey drainage. The research is in progress, for assessing the evolution of the volatile compounds during the next technological steps: curd stretching, mozzarella cooling, and packaging.

\section{Razvoj hlapivih mliječnih spojeva u grušu tijekom proizvodnje sira Mozarella}

\section{Sažetak}

Cilj ovog rada bio je istražiti razvoj hlapivih mliječnih spojeva (VOC) u grušu tijekom proizvodnje sira Mozzarella, ovisno o načinu zakiseljavanja sirnog gruša (tradicionalno = prirodno zakiseljavanje sirutke starter kulturama; industrijski = direktno zakiseljavanje dodatkom limunske kiseline). Iz svih testiranih uzoraka identificirano je ukupno oko 40 spojeva različitog kemijskog sastava. Svi spojevi pronađeni u mlijeku bili su prisutni i u grušu, no u puno višim koncentracijama. Osim toga, u gruševima su bili prisutni i mnogi drugi spojevi. Usporedbom uzoraka zakiseljenih na 2 različita načina utvrđeno je kako je mikrobna aktivnost igrala presudnu ulogu u formiranju VOC. Točnije, gruš zakiseljen prirodnim putem (starter kulturom) imao je najsloženiji profil VOC, dok je gruš zakiseljen dodatkom limunske kiseline bio puno jednostavnijeg sastava. Spojevi koji su u prirodno zakiseljenom grušu najviše doprinosili formiranju okusa i mirisa bili su 3-metilbutanal, etil acetat i 2,3-butandion, a koji su inače nosioci mirisa po 
eteru, voću i maslacu. U slučaju gruša zakiseljenog dodatkom limunske kiseline, glavni nosioci okusa i mirisa bili su 3-metilbutanal (niska koncentracija), nonanal i dekanal (biljno/voćni miris). PCA analiza je pokazala da dolazi do klasterizacije tri uzorka - mlijeka i gruševa zakiseljenih dodatkom limunske kiseline, dok su prirodno zakiseljeni gruševi bili raspoređeni u širem području. U tijeku je istraživanje kojem je cilj odrediti razvoj hlapivih spojeva tijekom preostalih tehnoloških koraka u procesu proizvodnje sira Mozzarella.

\section{Ključne riječi: hlapivi organski spojevi, mlijeko, gruš, Mozzarella, zakiseljavanje}

\section{References}

1. Afzal, M.I., Gonzalez Ariceaga, C.C., Boulahya, K., Jacquot, M., Delaunay, S., Cailliez-Grimal, C. (2017): Biosynthesis and role of 3-methylbutanal in cheese by lactic acid bacteria: Major metabolic pathways, enzymes involved, and strategies for control. Critical Reviews in Food Science and Nutrition 57 (2), 399-406. https://doi.org/10.1080/10408398.2014.893502

2. Bassette, R., Turner, M.E., Ward, G. (1966): Volatile compounds in blood milk and urine of cows fed silagegrain bromegrass pasture and hay-grain test meals. Journal of Dairy Science 49 (7), 811-812. https://doi.org/10.3168/jds.s0022-0302(66)87951-1

3. Bertuzzi, A.S., McSweeney, P.L.H., Rea, M.C., Kilcawley, K.N. (2018): Detection of volatile compounds of cheese and their contribution to the flavor profile of surface-ripened cheese. Comprehensive Reviews in Food Science and Food Safety 17 (2), 371-90. https://doi.org/10.1111/1541-4337.12332

4. Binetti, A., Carrasco, M., Reinheimer, J., Suarez, V. (2013): Yeasts from autochthonal cheese starters: technological and functional properties. Journal of Applied Microbiology 115 (2), 434-444. https://doi.org/10.1111/jam.12228

5. Blank, I., Sen, A., Grosch, W. (1992): Aroma impact compounds of arabica and robusta coffee. Qualitative and quantitative investigations. $14^{\text {th }}$ International Colloquium on the Chemistry of Coffee (San Francisco, 14-19.7.1991) (ASIC, 1992): 117-29.

6. Burdock, G.M. (2005): Fenaroli's handbook of flavour ingredients. $5^{\text {th }}$ edn. Boca Raton, USA: CRC Press.

7. Buttery, R. G., Turnbaugh, J.G., Ling, L.C. (1988): Contribution of volatiles to rice aroma. Journal of Agricultural and Food Chemistry 36 (5), 1006-1009. https://doi.org/10.1021/jf00083a025

8. Buttery, R.G., Teranishi, R., Ling, L.C., Turnbaugh, J.G. (1990): Quantitative and sensory studies on tomato paste volatiles. Journal of Agricultural and Food Chemistry 38 (1), 336-340. https://doi.org/10.1021/jf00091a074

9. Contarini, G., Povolo, M., Leardi, R., Toppino, P.M. (1997): Influence of heat treatment on the volatile compounds of milk. Journal of Agricultural and Food Chemistry 45 (8), 3171-77. https://doi.org/10.1021/jf960849s
10. Czerny, M., Christlbauer, M., Christlbauer, M., Fischer, A., Granvogl, M., Hammer, M., Hartl, C., Moran-Hernandez, N., Schieberle, P. (2008): Re-investigation on odour thresholds of key food aroma compounds and development of an aroma language based on odour qualities of defined aqueous odorant solutions. European Food Research and Technology 228 (2), 265-273. https://doi.org/10.1007/s00217-008-0931-x

11. Dursun, A., Güler, Z., Şekerli, Y.E. (2017): Characterization of volatile compounds and organic acids in ultrahigh-temperature milk packaged in tetra brik cartons. International Journal of Food Properties. 20 (7), 1511-1521. https://doi.org/10.1080/10942912.2016.1213280

12. Faccia, M., Gambacorta, G., Natrella, G., Caponio, F. (2019): Shelf life extension of Italian mozzarella by use of calcium lactate buffered brine. Food Control 100, 287-291. https://doi.org/10.1016/j.foodcont.2019.02.002

13. Faccia, M., Trani, A., Gambacorta, G., Loizzo, P., Cassone, A., Caponio, F. (2015): Production technology and characterization of Fior di latte cheeses made from sheep and goat milks. Journal of Dairy Science 98 (3), 1402-1410. https://doi.org/10.3168/jds.2014-7953

14. Faccia, M., Trani, A., Loizzo, P., Gagliardi, R., La Gatta, B., Di Luccia, A. (2014): Detection of as $1-$ I casein in mozzarella Fiordilatte: A possible tool to reveal the use of stored curd in cheesemaking. Food Control 42, 101-108. https://doi.org/10.1016/j.foodcont.2014.01.044

15. Fors, S. (1988): Sensory properties of volatile Maillard reaction products and related compounds in the Maillard reaction in foods and nutrition. ACS Symposium Series 215 , G. R. Waller and M. S. Feather, Editors, ACS, Washington 215 : 185-286. https://pubs.acs.org/doi/abs/10.1021/bk-19830215.ch012 (12.11.2019). https://doi.org/10.1021/bk-1983-0215.ch012

16. Guidone, A., Zotta, T., Matera, A., Ricciardi, A., De Filippis, F., Ercolini, D., Parente, E. (2016): The microbiota of high-moisture mozzarella cheese produced with different acidification methods. International Journal of Food Microbiology 216, 9-17. https://doi.org/10.1016/j.jifoodmicro.2015.09.002

17. IDF. 1986. Cheese and processed cheese products: Determination of dry matter. IDF Standard 4. International Dairy Federation (IDF), Brussels, Belgium. 
18. McMahon, D.J., Oberg, C.J. (2017): Pasta Filata Cheeses in Cheese: Chemistry, Physics and Microbiology, $4^{\text {th }}$ Edition, McSweeney, PLH, Fox, PF, Cotter PD and Everett, DW. Academic Press, Camridge, USA 1041-1068. https://doi.org/10.1016/b978-0-12-417012-4.00040-5

19. McSweeney, P.L.H., Sousa, M.J. (2000): Biochemical pathways for the production of flavor compounds in cheeses during ripening: A review. Lait 80 (3), 293-324. https://doi.org/10.1051/lait:2000127

20. Moio, L., Dekimpe, J., Etievant, P.X., Addeo, F. (1993): Comparison of the neutral volatile compounds in mozzarella cheese made from bovine and water buffalo milk. Italian Journal of Food Science (3), 215-225.

21. Partidário, A. M., Barbosa, M., Vilas Boas, L. (1998): Free fatty acids, triglycerides and volatile compounds in Serra Da Estrela Cheese - Changes throughout Ripening. International Dairy Journal 8 (10-11), 873-81. https://doi.org/10.1016/s0958-6946(98)00131-9

22. Pisano, M. B., Scano, P., Murgia, A., Cosentino, S., Caboni, P. (2016): Metabolomics and microbiological profile of Italian mozzarella cheese produced with buffalo and cow milk. Food Chemistry 192, 618-624. https://doi.org/10.1016/j.foodchem.2015.07.061
23. Trani, A., Gambacorta, G., Loizzo, P., Cassone, A., Faccia, M. (2016): Un contributo alla caratterizzazione della treccia pugliese a sieroinnesto. Industrie Alimentari. 2016 569, 3-10.

24. Trani, A., Gambacorta, G., Loizzo, P., Cassone, A., Fasciano, C., Zambrini, V.A., Faccia, M (2017): Comparison of HPLC-RI, LC-MS and enzymatic assays for the analysis of residual lactose in lactose-free milk. Food Chemistry 233, 385-390. https://doi.org/10.1016/j.foodchem.2017.04.134

25. Valero, E., Villamiel, M., Miralles, B., Sanz, J. (2001): Changes in flavour and volatile components during storage of whole and skimmed UHT milk. Food Chemistry 72 (1), 51-58. https://doi.org/10.1016/s0308-8146(00)00203-x

26. Vazquez-Landaverde, P.A., Velazquez, G., Torres, J.A., Qian, M.C. (2005): Quantitative determination of thermally derived off-flavor compounds in milk using solid-phase microextraction and gas chromatography. Journal of Dairy Science 88 (11), 3764-3772. https://doi.org/10.3168/jds.s0022-0302(05)73062-9

27. Zeppa, G., Rolle, L. (2008): A study on organic acid, sugar and ketone contents in typical piedmont cheeses. Italian Journal of Food Science 20 (1), 127-139.

28. Yvon, M., Rijnen, L. (2001): Cheese flavour formation by amino acid catabolism. International Dairy Journal 11 (4), 185-201. https://doi.org/10.1016/s0958-6946(01)00049-8 